\title{
The Benefits of Simulated Coursework in Western Michigan University's Undergraduate Supply Chain Program
}

\author{
Emma Stuba, Sime Curkovic, Bret Wagner \\ Haworth College of Business, Center for Integrated Supply Management, Western Michigan University, Kalamazoo, \\ Michigan, USA \\ Email: emma.1.stuba@wmich.edu,sime.curkovic@wmich.edu,bret.wagner@wmich.edu
}

How to cite this paper: Stuba, E., Curkovic, S., \& Wagner, B. (2017). The Benefits of Simulated Coursework in Western Michigan University's Undergraduate Supply Chain Program. Creative Education, 8, 1821-1832. https://doi.org/10.4236/ce.2017.812125

Received: July 21, 2017

Accepted: September 23, 2017

Published: September 26, 2017

Copyright (c) 2017 by authors and Scientific Research Publishing Inc. This work is licensed under the Creative Commons Attribution International License (CC BY 4.0).

http://creativecommons.org/licenses/by/4.0/

\begin{abstract}
The demand for qualified supply chain professionals is growing more and more each year. Universities across the United States are working to prepare students entering the supply chain field as best they can. Experiential learning through simulated environments is one of the ways schools are working to get students job-ready day 1 . The Integrated Supply Management program at Western Michigan University utilizes a simulation in the Production Management and Control course to give students inventory control and demand planning experience to better prepare them for their full-time careers. This paper describes the current skill set demands of new college graduates, and how experiential coursework attempts to develop those skills. It also describes the simulated course required by the supply chain program.
\end{abstract}

\section{Keywords}

Supply Chain Management, Experiential Learning, Simulation, Gaming

\section{Introduction}

The shortage of skilled supply chain graduates is becoming a serious predicament for many businesses today (Bowman \& SupplyChainBrain, 2015). Supply chain professionals are in high demand due to the changing demographics of the workforce and the general importance of the supply chain in business (Cottrill, 2010). Yet, in spite of high demand, in their 2016 Annual Industry Report, MHI and Deloitte found that the biggest challenge companies continue to face is hiring and retaining a skilled workforce (MHI, 2017).

Even with the growing crop of supply chain graduates, there is still an empha- 
sis on developing the best supply chain talent internally. Through a survey on higher education conducted by Gallup and the Lumina Foundation, it was determined that only $11 \%$ of business leaders strongly believe undergraduate students come to the workforce prepared (Busteed, 2014; Gallup, Inc., 2014). Graduates are expected to continuously develop technical skills necessitated by the business environment as well as soft interpersonal skills (Badel, 2016); however, many of these skills cannot be taught in a lecture-style course. Institutions of higher learning, therefore, are now focusing on alternative teaching methods.

As new college graduates replace long-standing employees through attrition, soft skills become critical in making a successful transition to the workforce (Bowman \& SupplyChainBrain, 2013). Having the confidence, curiosity, and soft skills to appropriately vocalize that confidence and curiosity, for example, is what sets apart newly hired graduates. Table 1 provides a list of skills employers seek on a candidate's resume. Soft skills are often defined as aspects of emotional intelligence such as leadership, communication, teamwork, and problem solving skills. Working with a business simulation encourages independent decision-making and problem solving, and working in a group adds teamwork, leadership, and communication skills. The technical soft skills learned in courses with experiential learning components better prepare students for the workforce.

Table 1. Attributes employers seek on a candidate's resume (National Association of Colleges and Employers, n.d.).

\begin{tabular}{|c|c|}
\hline Attribute & Percentage of Respondents \\
\hline Leadership & 80.1 \\
\hline Ability to work on a team & 78.9 \\
\hline Communication skills (written) & 70.2 \\
\hline Problem solving skills & 70.2 \\
\hline Communication skills (verbal) & 68.9 \\
\hline Strong work ethic & 68.9 \\
\hline Initiative & 65.8 \\
\hline Analytical/quantitative skills & 62.7 \\
\hline Flexibility/adaptability & 60.9 \\
\hline Technical skills & 59.6 \\
\hline Interpersonal skills (relates well to others) & 58.4 \\
\hline Computer skills & 55.3 \\
\hline Detail-oriented & 52.8 \\
\hline Organizational ability & 48.4 \\
\hline Friendly/outgoing personality & 35.4 \\
\hline Strategic planning skills & 26.7 \\
\hline Creativity & 23.6 \\
\hline Tactfulness & 20.5 \\
\hline Entrepreneurial skills/risk-taker & 18.6 \\
\hline
\end{tabular}


Even with high demand for supply chain talent, students need to realize a benefit to their coursework and feel prepared upon graduation. Most collegiate-level courses focus on teaching technical skills, while employers seek both the technical and soft skills required in the work environment. Undergraduate supply chain programs are moving towards developing students through experiential learning courses because students are taught technical and soft skills through a dynamic and interactive environment (WMU, 2015).

The supply chain is the intermediate agent between many aspects of a business, making it critical to prepare students who can handle high-pressure situations and are job-ready on day 1 following graduation. Supply chain is a discipline that requires students to make decisions and invent new solutions, which forces students to have an understanding of both tactical and strategic decision-making (Cottrill, 2010). The jobs in supply chain are rapidly fluctuating as well. The ever-changing nature of technology coupled with new responsibilities makes it difficult to find skilled professionals that satisfy job requirements. This situation will only grow in the new few years as more disruptive technologies enter the market, changing job requirements and desired qualities (MHI, 2107). Moreover, the lack of supply chain professionals due to increasing demand puts further pressure on undergraduate programs to fully prepare students for their entry-level positions (Holcomb, Krul, \& Thomas, 2015).

Western Michigan University's (WMU) Integrated Supply Management (ISM) program focuses on creating value for the student while meeting the needs of supply chain professionals through its experiential learning coursework. WMU has incorporated experiential learning through simulated experiences into their ISM curriculum using a course focused on demand planning and inventory control. The course is called Production Management and Control (MGMT 4640), and utilizes software called ScrimaggeSim, which was created by the course professor. The ISM program at WMU is an interdisciplinary, 43 credit hour program encompassing purchasing, logistics, operations management, and engineering courses. The focus on information technology and experiential learning has given WMU's ISM program impressive rankings from external publications. The ISM program at WMU is ranked 2nd for undergraduate programs by SCM World (WMU, n.d.), 2nd for information technology by Software Advice (Burnson, 2015), and 9th for undergraduate supply chain programs by Gartner, Inc. (2016).

\section{The Student}

Rehearsing terms and examples as opposed to being able to apply those concepts separates students upon graduation in their field. Furthermore, students who are able to make decisions based on their knowledge from the classroom will be more creative problem solvers in the business world (Feinstein, Mann, \& Corsum, 2002). Given that undergraduate students often lack real life experience when applying for internships and jobs, and experiential education offers skills 
and experience comparable to real job expertise. Experiential learning has gained traction in supply chain undergraduate education because many students do not have the work experience necessary to understand how their conceptual learning translates in supply chain (Webb, Thomas, \& Liao-Troth, 2014). Employers reap the benefits of curriculum focused on experiential learning because students are learning more than just the supply chain concepts they need. Using coursework designed to promote student interaction with material close to "real life" forces them to think atypically when compared to a lecture scenario. Additionally, aside from learning how to apply concepts in a supply chain position, many soft skills are gained in experiential learning classes. In fact, findings demonstrate that experiential learning increases learners' capacity to evoke higher-order cognitive abilities in terms of problem solving skills and judgment (Feinstein et al., 2002). Students are expected to learn how to evaluate a situation and make a decisions based on the information provided, and a simulation provides many variables that incorporate complexities of decision-making.

Experiential learning not only forces students to think creatively in the classroom, but it also trains students to think critically in every scenario outside of the classroom. Experiential learning exercises conducted in a group encourage students to interact and develop communication, leadership, and teamwork skills necessary in the workplace. Employers are taking courses into account that require students to work in an interactive environment that represents the real world. These students learn more than theories, and have already begun to apply their knowledge and see how their decisions would affect a supply chain. This paper examines supply chain courses from WMU and their effect on preparing undergraduate students for supply chain careers.

\section{The Business}

The ISM program has grown each year since its inception in 1992, and continues to demonstrate unique and effective curriculum. The ISM program requires 43 credit hours and includes courses in the College of Engineering and Applied Sciences to provide and interdisciplinary education that will aid students working on cross-functional teams (WMU, n.d.). Table 2 summarizes the required credit hours of major program competitors. In addition to a strong curriculum, students have a $96 \%$ satisfaction rate upon graduation, and an average median salary between $\$ 55,000$ and $\$ 60,000$ (WMU, 2015). Table 3 shows some of the

Table 2. Required credit hours of major program competitors ${ }^{\mathrm{a}}$.

\begin{tabular}{cc}
\hline Program & Credit Hours \\
\hline Integrated Supply Management, WMU & 43 \\
Supply Chain Management, Arizona State University & 21 \\
Supply Chain Management, Michigan State University & 18 \\
Supply Chain Management, Penn State University & 24 \\
Supply Chain Management, University of Texas, Austin & 21 \\
\hline
\end{tabular}

a. Retrieved from https://wmich.edu/supplychain/academics. 
Table 3. Sample job titles and employers of WMU ISM graduates.

\begin{tabular}{|c|c|}
\hline \multicolumn{2}{|c|}{ Sample Job Titles and Employers } \\
\hline API Training Specialist at Pfizer & Operations Manager at Amazon \\
\hline Associate Manager-Capacity Planning at Kellogg & Planning Business Analyst at Haworth \\
\hline Associate Sales Executive at C.H. Robinson & Procurement Agent at Boeing \\
\hline Associate Sourcing Specialist at Whirlpool & Procurement Analyst at Atkore International \\
\hline Buyer at DENSO & Procurement Technician at Pfizer \\
\hline Buyer at Fiat Chrysler Automobiles & $\begin{array}{l}\text { Product/Quality Engineer at Dunkley } \\
\text { International }\end{array}$ \\
\hline Buyer at Flowserve & Production Coordinator at National Flavors \\
\hline Buyer at Ford Motor Company & Production Supervisor at Detroit Diesel \\
\hline Buyer at Honda Motors & Production Support Engineer at Gentex \\
\hline Buyer/Planner at Grayhill & Project Manager at Woolf Aircraft Products \\
\hline Category Analyst at S.C. Johnson & Purchasing at Command Electronics \\
\hline Consultant at Auditrax & $\begin{array}{c}\text { Purchasing and Inventory Manager at Western } \\
\text { Diversified Plastics }\end{array}$ \\
\hline Cost Planning Specialist at DENSO & Replacement Analyst at Viking \\
\hline $\begin{array}{l}\text { Data Analyst/Quality Control Manager at Swiss } \\
\text { American Screw Products }\end{array}$ & SCM Program Manager at Eaton \\
\hline Demand Planner at Kellogg & Senior Buyer at Honda \\
\hline Dispatch at RSVP International Logistics & Sourcing Specialist at Whirlpool \\
\hline Functional Consultant at Oracle & $\begin{array}{l}\text { Subcontracts Manager at NASA Jet Propulsion } \\
\text { Lab }\end{array}$ \\
\hline Global Forwarding Agent at C.H. Robinson & Supplier Quality Engineer at General Motors \\
\hline $\begin{array}{l}\text { Global Purchasing and Supply } \\
\text { Chain at General Motors }\end{array}$ & Supplier Sourcing Specialist at Navistar \\
\hline Global Supply Chain Analyst at Mercury Marine & $\begin{array}{l}\text { Supply Chain Analyst at Beaumont Health } \\
\text { System }\end{array}$ \\
\hline Indirect Buyer at Yanfeng USA & Supply Chain Analyst at General Motors \\
\hline International Logistics Analyst at Stryker & Supply Chain at Lacks Trim Systems \\
\hline Inventory Control Analyst at Meijer & Supply Chain Analyst at Meijer \\
\hline Lead Visual Designer at ProQuest & Supply Chain Analyst at Techniq \\
\hline Logistics Coordinator at MidLink Logistics & Supply Chain Associate at Havi Global Solutions \\
\hline $\begin{array}{l}\text { Manufacturing Planner Associate at Lockheed } \\
\text { Martin }\end{array}$ & Supply Chain Commodity Specialist at Haworth \\
\hline Market Analyst at Constellation Brands & $\begin{array}{c}\text { Supply Chain Data Analyst at Applied Industrial } \\
\text { Technologies }\end{array}$ \\
\hline Material Planner at Flowserve & Supply Chain Specialist at Kohler \\
\hline Material Planner at Parker Hannifin & Supply Chain Planner/Scheduler at Emerald \\
\hline Material Planner at TRMI & Supply Chain Specialist at Magna International \\
\hline Material Planning Specialist at DENSO & Supply System Improvement at Impact Label \\
\hline Materials Analyst at Brembo North America & Transportation Manager at Warner Enterprises \\
\hline ort Engineer at Gentex & \\
\hline
\end{tabular}


job titles and employers of graduates.

One of the reasons employers hire students from the ISM program at WMU is the technical skills students develop (see Table 4). Students have unique coursework that gives them more experiential learning opportunities to develop their technical skills. One new addition to the ISM coursework is a dynamic simulation, ScrimmageSim, to the demand planning course.

Simulations for supply chain undergraduate curriculum are becoming more significant because they offer experiential learning opportunities, which prove to be more valuable that traditional lecture-style coursework. For the purpose of this paper, a simulation is defined as "a well-established technique that duplicates the 'features, appearances, and characteristics' of a real business or management system through an iconic or symbolic model" (Feinstein et al., 2002). Experiential learning is defined as a learning method that requires students to do more than listen to a lecture and study for an exam. Students must be fully engaged to perform well. Working in a simulated environment focuses on bridging the gap between theoretical concepts and concrete applications (Webb et al., 2014).

The completely immersive nature of simulated coursework has proven to be a valuable classroom tool, and the trend has only grown in the past few years. In 1974, research started comparing styles of teaching, and the results lend themselves towards recognition of the positive influence of simulated experiences in the classroom (Faria, 2001). Also in 1974, a member of the Association for Business Simulation and Experiential Learning (ABSEL) compared exam scores of two courses: one traditional and one based around a game. When comparing the scores of the exam, "At a 0.01 level of significance, the game-centered section students outscored the lecture-centered students on both the course midterm and final" (Faria, 2001). Additional studies have also been completed through

Table 4. Reasons companies hire WMU students.

\begin{tabular}{c} 
Reason \\
\hline Breadth and depth of program, program ranking, and program curriculum \\
Comfort level on multi-disciplinary teams, asking questions \\
Demonstrated success \\
Drive, energy, and passion of students \\
Effective projects and internships \\
Multi-tasking capabilities \\
Quality engineering standards and knowledge \\
Students desire to outperform larger programs \\
Support from faculty \\
Technical apptitude \\
Willingness and eagerness of students
\end{tabular}


ABSEL, with results indicating that simulation-centered courses have a higher performance standard on exams.

The ISM program at WMU utilizes a simulation in one specific course to set their undergraduate supply chain students up for success. The course that involves a simulated environment at WMU is taught by Dr. Bret Wagner, an Associate Professor of Management. He created this course to mimic the work environment and processes students will follow in their early careers. The course is updated on a semester basis to ensure the learning objectives align with industry needs.

\section{Product Management and Control}

Production Management and Control was created to teach students how material planning works and tactics they can utilize in their future careers. Adding a simulated component has been an idea of Dr. Wagner's since 1992, and was recently implemented in 2015. The cloud-based simulation, ScrimmageSim, adds a dynamic piece to the classroom. Students compete with others in real time in short exercises and long competitions. This course is reserved for upperclassmen with the supply chain introduction course completed, allowing students to take this course and apply it in an internship. The course description reads, "Quantitative and computer-based methods of planning and controlling operations in manufacturing are explored. Topics covered in depth include forecasting, production planning and inventory control. The course employs a problem-based approach using in-class problems, spreadsheet analysis, enterprise system applications and simulations" (Wagner, 2016).

Simulations are used in two ways in the course. First, simulations are used to introduce students to a topic and provide context to better understand theory and tools available to address the business problem. Second, simulations are used to provide students with an opportunity to apply the tools and theory they have learned. This specific course was designed to give WMU's ISM students demand planning experience, especially with many students graduating into a material planning role, and all students needing to understand the concepts behind material planning and forecasting.

\subsection{Course Description}

Production Management and Control is taught with a traditional two class periods per week schedule; however, 2 weeks in the semester are reserved for an exam and week-long simulation. The exams are online and students are allowed to take the exam as many times as they want, with the best score being used for the student's grade. Each exam has a bank of problem solving questions for each topic, and many of the questions also use random problem parameters. This approach allows students to develop mastery of the subject. During the exam period, students also participate in a week-long simulation that provides context for the next topic to be covered in class. The topics covered in the classroom in- 
clude learning curves, economic order quantity (EOQ), economic production quantity (EPQ), safety stock, economic lot scheduling, materials requirements planning (MRP), and various forecasting models. Production Management and Control is a course based around demand planning that utilizes a simulated game to give students experience in this area. The course objectives are as follows:

- Have an in-depth understanding of the complex nature of production management and control.

- Understand the wide variety of problems in this area, and by understanding this complexity, understand how to manage planning and control problems in the real world.

- Apply planning and control concepts through the ScrimmageSim business simulation and practice in Microsoft Excel.

Students have out of class assignments that require them to take the information learned in the lecture to create Microsoft Excel spreadsheet tools such as EOQ, EPQ, and safety stock. Additionally, students work on ScrimmageSim simulations both in and out of class. ScrimmageSim provides different company scenarios to illustrate a particular concept. Some simulation scenarios have students use the simulation in an experimental fashion. For example, students are introduced to the EOQ problem by making reorder decisions for a convenience store and seeing how the order quantity impacts the company's bottom line. In other simulations, students work in pairs to operate the company. The interaction allows students to develop both teamwork and communication skills, while emphasizing problem solving and decision-making skills. In all simulations, students compare their performance to their teammates' to encourage competition and engagement.

\subsection{Alignment with Undergraduate Program Goals}

This course builds on many principles of foundational business coursework, including statistics, accounting, economics, operations, and finance. Students work with various forecasting models and inventory control methods in a problem-based learning atmosphere to meet the learning objectives of the College of Business. Additionally, this course is continuously analyzed by both students and professionals to determine the best information and delivery method. The ISM program at WMU involves an Industry Advisory Council formed from supply chain managers that recruit from the program, which meets twice a year to discuss the curriculum. Students also evaluate the course to fine-tune the best ways of delivering the information.

\subsection{Course Pedagogy}

Students in Production Management and Control start by learning the basics of inventory management, material planning, and forecasting. As stated, specific topics include EOQ, safety stock, EPQ, economic lot scheduling, MRP, and time 
series forecasting. The course is taught through lecture and simulated exercises, with students applying what they learned in a dynamic environment.

The goal of this teaching style is to introduce students to necessary concepts and to teach them problem solving skills, as well as important concepts they will encounter in their entry-level positions and beyond.

\subsection{Spreadsheet Assignments}

Spreadsheet assignments are utilized to assess understanding of conceptual principles, as well as to teach students how to build and manipulate a spreadsheet. Spreadsheets are constructed in Microsoft Excel and graded on the accuracy of the calculations, as well as correct formatting. The images in Figure 1 and Figure 2 below are samples of spreadsheet assignments required by the course.

\subsection{Testing}

Three tests are completed over the course of the semester, with a final exam at the end. Tests consist of both conceptual and quantitative questions. The tests are conducted through the university E-learning system, with the test being open throughout the time period. Students can test as often as they want. This allows students to get more experience with the problems, as well as ensure they are learning the material. The questions vary over each run of the test, so students cannot use answers from previous tests they have taken.

\subsection{ScrimmageSim}

The main instructional method of the course is ScrimmageSim, a simulation

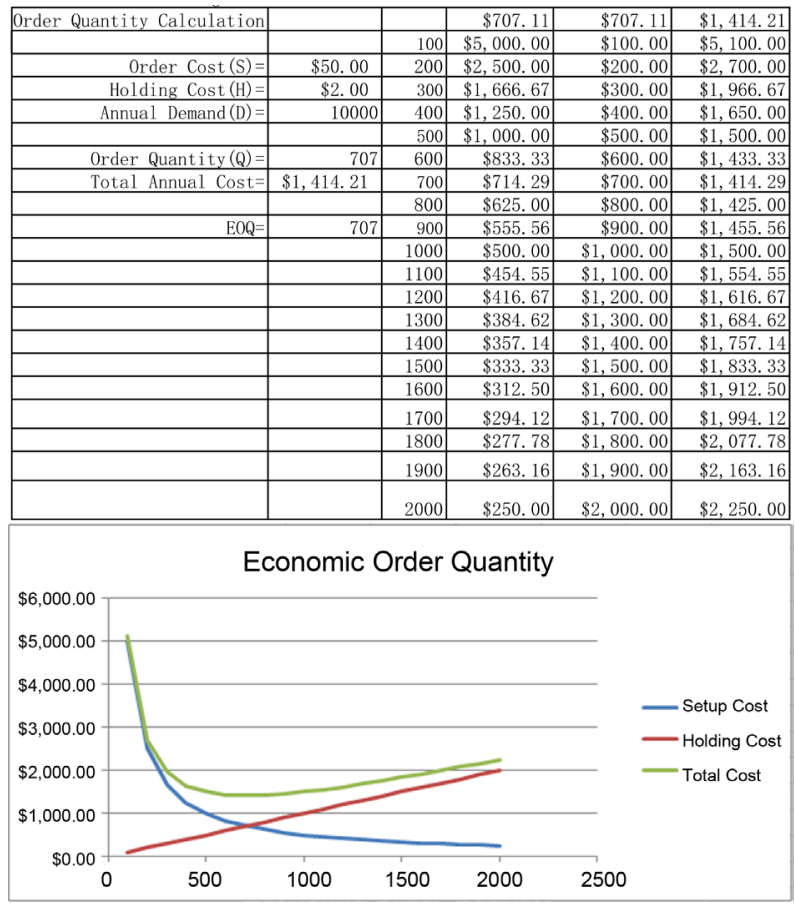

Figure 1. EOQ calculations. 


\begin{tabular}{|l|c|c|c|c|}
\hline Parameter & Product 1 & Product 2 & Product 3 & Total \\
\hline Demand $d$ & 1000 & 1200 & 800 & \\
\hline Production Rate $p$ & 4000 & 4000 & 3200 & \\
\hline Setup time (days) & 0.5 & 0.5 & 0.5 & 1.5 \\
\hline Setup Cost & $\$ 1,200.00$ & $\$ 1,400.00$ & $\$ 2,000.00$ & \\
\hline Holding Cost \$/unit/day & $\$ 0.05$ & $\$ 0.06$ & $\$ 0.10$ & \\
\hline$d / p$ & 0.25 & 0.3 & 0.25 & \\
\hline & & & & \\
\hline Min. Cycle Time & 7.5 & & & \\
\hline & & & & \\
\hline Cycle Time (T) & & & & \\
\hline 10.0 & & & & \\
\hline & Product 1 & Product 2 & Product 3 & Total \\
\hline Demand/Cycle & 10000.0 & 12000.0 & 8000.0 & \\
\hline Production Time & 2.5 & 3.0 & 2.5 & \\
\hline Setup time & 0.5 & 0.5 & 0.5 & \\
\hline Total Time & 3.0 & 3.5 & 3.0 & 9.5 \\
\hline & & & & \\
\hline Setup Cost/Day & $\$ 120.00$ & $\$ 140.00$ & $\$ 200.00$ & $\$ 460.00$ \\
\hline Average Inventory & 3750.0 & 4200.0 & 3000.0 & \\
\hline Inventory Cost/Day & $\$ 187.50$ & $\$ 252.00$ & $\$ 300.00$ & $\$ 739.50$ \\
\hline & & Total Daliy Cost= & $\$ 1,199.50$ \\
\hline
\end{tabular}

Figure 2. ELSP calculations.

created to give students dynamic experience with demand planning. Students are given a beer production environment with historical demand data, and the course instructor has the ability to change the independent and dependent variable. For example, the instructor can dictate if students enter their plans and advance time manually, or if time advances automatically. Another option is to allow students to set pricing for each product.

Students start out with small exercises designed to familiarize them with the system and to allow them to test out strategies. After learning the principles via lecture, students then apply principles in a simulated environment to understand how the simulation works. For small exercises, students can "re-do" runs and test out what approach works the best. As students become more advanced in the system, longer week-long simulations are conducted without the ability to start over or complete runs more than once.

\subsection{Student Feedback}

Students have the opportunity to rate the course and give their feedback after the semester has ended. Figure 3 and Figure 4 present screenshots of two aspects of the evaluation for a semester (WMU, 2015).

As demonstrated by the results of the evaluations, students find the course to be extremely relevant and helpful towards their future career paths.

\section{Outcomes and Conclusion}

Ultimately, the use of simulations to create experiential learning opportunities in WMU's ISM curriculum attempts to give students more experiential learning opportunities than a traditional lecture formatted course. In particular, the unique structure of Production Management and Control promotes dynamic learning that not only will give students the technical skills they need upon-graduation, 


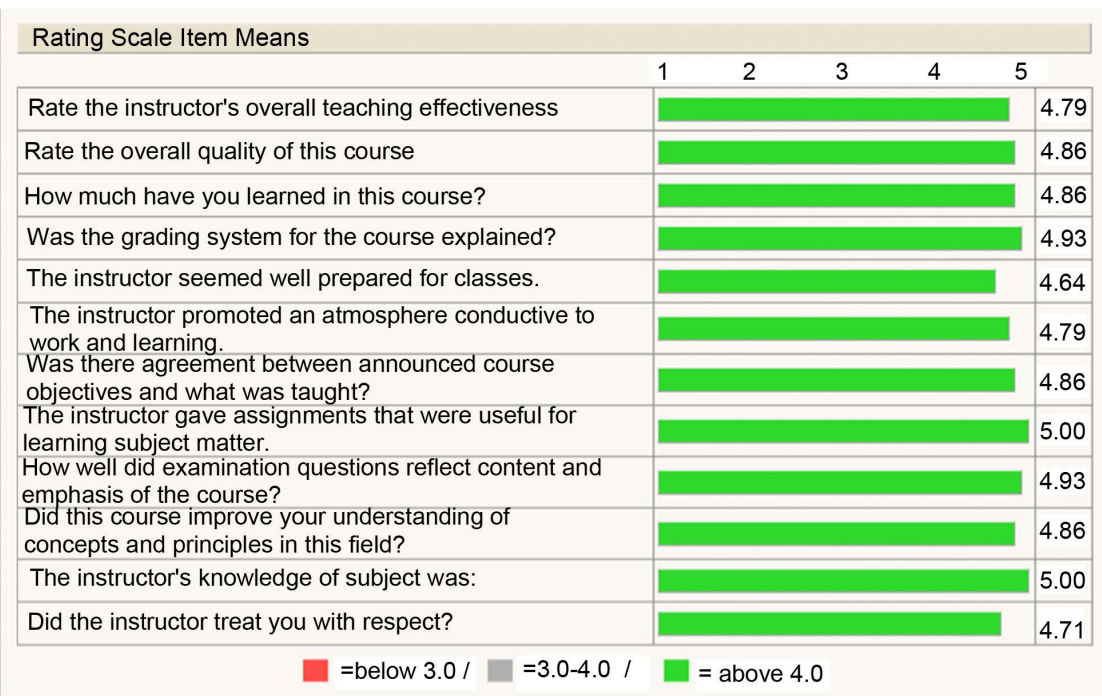

Figure 3. Quantitative course feedback.

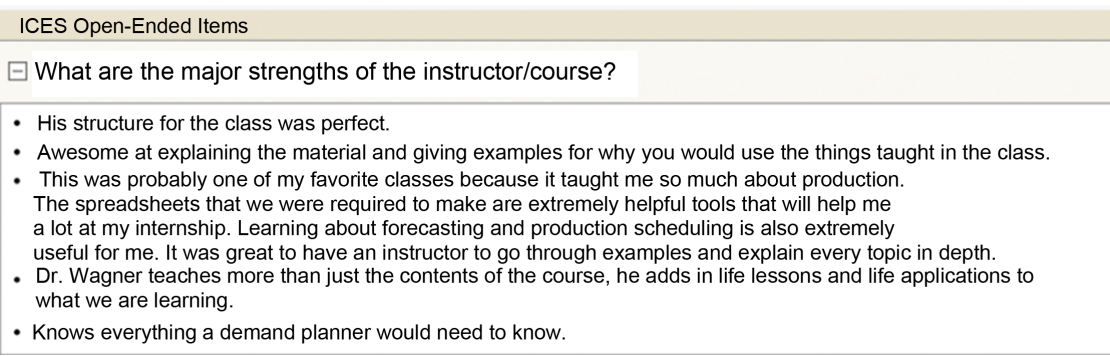

Figure 4. Qualitative feedback on course strengths.

but the interpersonal soft skills demanded by employers.

\section{References}

Badel, S. B. (2016). Skills Learned in School Differ from Those Demanded at Work. Gallup Business Journal.

http://www.gallup.com/businessjournal/188828/skills-learned-school-differ-demanded -work.aspx?g_source=GALLUP_LUMINA\&g_medium=topic\&g_campaign=tiles

Bowman, R. J., \& SupplyChainBrain (2013). Bridging the Talent Gap in Supply-Chain Management.

http://www.supplychainbrain.com/content/blogs/think-tank/blog/article/bridging-thetalent-gap-in-supply-chain-management/

Bowman, R. J., \& SupplyChainBrain (2015). The Supply-Chain Talent Gap is Wider Than You Think.

http://www.supplychainbrain.com/content/blogs/think-tank/blog/article/the-supply-ch ain-talent-gap-is-wider-than-you-think/

Burnson, F. (2015). The Top Universities for Supply Chain Technology Education. http://www.softwareadvice.com/resources/top-universities-for-scm-report-2015/

Busteed, B. (2014). Higher Education's Work Preparation Paradox.

http://www.gallup.com/opinion/gallup/173249/higher-education-work-preparation-pa radox.aspx?g_source-GALLUP_LUMINA\&g_medium=topic\&g_campaign=tiles

Cottrill, K. (2010). Are You Prepared for the Supply Chain Talent Crisis? (MIT CTL 
White Paper).

https://www.plantservices.com/assets/Media/1011/WP_TalentShortage.pdf

Faria, A. (2001). The Changing Nature of Business Simulation/Gaming Research: A Brief History. Simulation and Gaming, 32, 97-110.

https://doi.org/10.1177/104687810103200108

Feinstein, A. H., Mann, S., \& Corsun, D. (2002). Charting the Experiential Territory: Clarifying Definitions and Uses of Computer Simulation, Games, and Role Play. Journal of Management Development, 21, 732-744. https://doi.org/10.1108/02621710210448011

Gallup, Inc. (2014). The 2013 Lumina Study of the American Public's Opinion on Higher Education and U.S. Business Leaders Poll on Higher Education: What America Needs to Know about Higher Education Redesign.

https://www.luminafoundation.org/files/resources/2013-gallup-lumina-foundation-rep ort.pdf

Gartner, Inc. (2016). Survey Analysis: Top 25 North American Supply Chain Undergraduate University Programs, 2016. Stamford, CT: Author.

Holcomb, M., Krul, A., \& Thomas, D. (2015). Supply Chain Talent Squeeze: How Business \& Universities Are Collaborating to Fill the Gap. Supply Chain Management Review, 19, 10-18.

MHI (2017). The 2016 MHI Annual Industry Report.

https://www.mhi.org/publications/report

National Association of Colleges and Employers (n.d.). Job Outlook 2016: Attributes Employers Want to See on New College Graduates' Resumes. http://www.naceweb.org/s11182015/employers-look-for-in-new-hires.aspx

Wagner, D. B. (2016). MGMT 4640 Production Management and Control. In M. I. Kalamazoo (Ed.), Integrated Supply Management Program. Western Michigan University.

Webb, G. S., Thomas, S. P., \& Liao-Troth, S. (2014). Teaching Supply Chain Management Complexities: A SCOR Model Based Classroom Simulation. Decision Sciences Journal of Innovation Education, 12, 181-198. https://doi.org/10.1111/dsji.12038

Western Michigan University (WMU) (2015). 2015 Annual Report. https://wmich.edu/sites/default/files/attachments/u205/2016/Zhang\%202015\%20Annu al\%20report-clickable.pdf

Western Michigan University (WMU) (n.d.). Academics.

https://wmich.edu/supplychain/academics

Submit or recommend next manuscript to SCIRP and we will provide best service for you:

Accepting pre-submission inquiries through Email, Facebook, LinkedIn, Twitter, etc.

A wide selection of journals (inclusive of 9 subjects, more than 200 journals)

Providing 24-hour high-quality service

User-friendly online submission system

Fair and swift peer-review system

Efficient typesetting and proofreading procedure

Display of the result of downloads and visits, as well as the number of cited articles

Maximum dissemination of your research work

Submit your manuscript at: http://papersubmission.scirp.org/

Or contact ce@scirp.org 